\title{
Papillary thyroid carcinoma variants with tall columnar cells
}

\author{
Chan Kwon Jung \\ Department of Hospital Pathology, College of Medicine, The Catholic University of Korea, Seoul, Korea
}
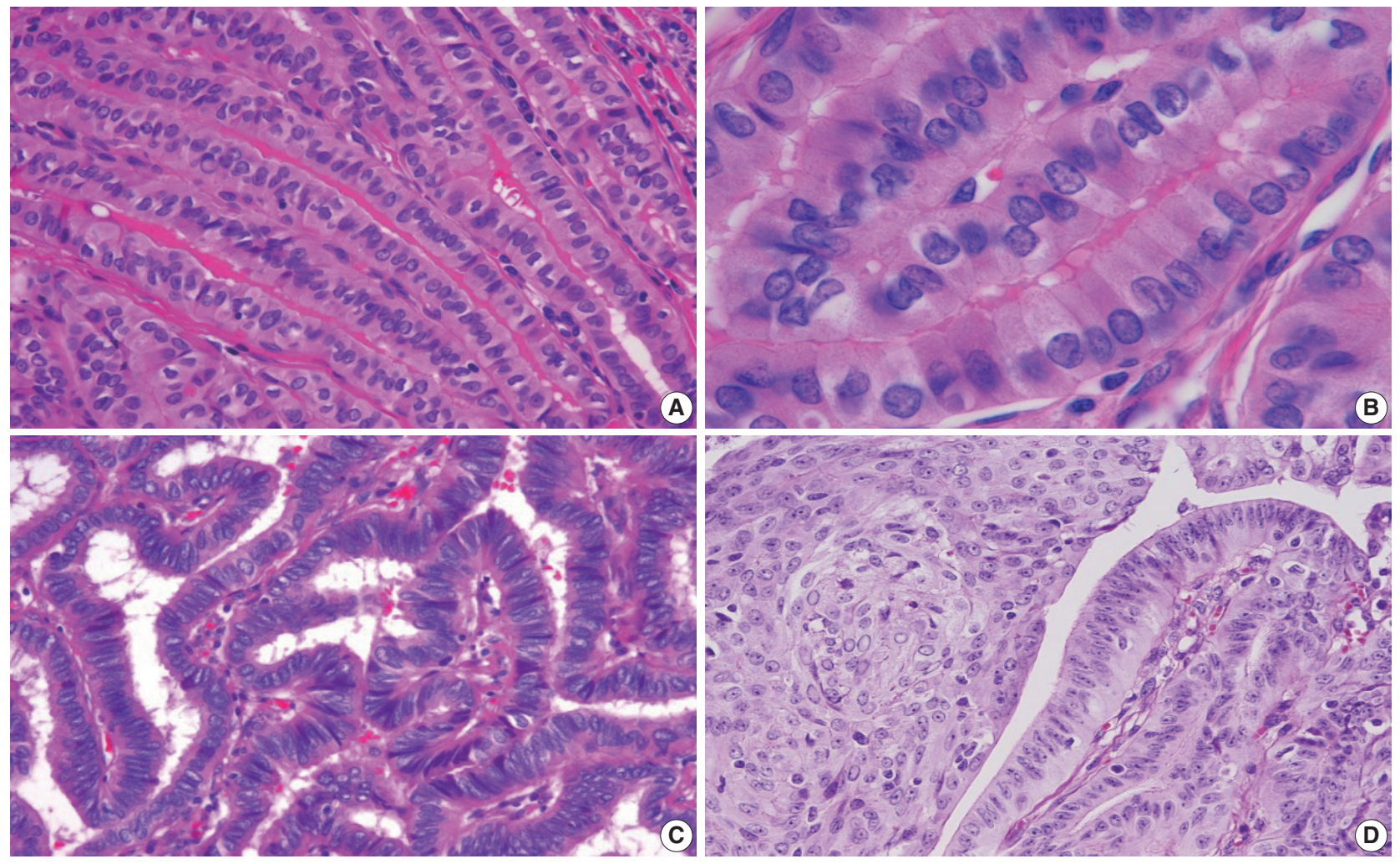

Tall columnar cells can be seen in different variants of papillary thyroid carcinoma (PTC). Tall cell variant of PTC shows elongated and closely packed follicles lined by a single layer of tall cells producing a so-called "tram-track" appearance (A). High-power view showing tall cells (at least twice as tall as wide) with nuclear features of PTC, intensely eosinophilic cytoplasm, and sharply delineated cell borders. The nuclei are basally located (B). Columnar cell variant of PTC shows tightly packed papillae lined by pseudostratified tall columnar cells with elongated dark nuclei. The nuclear features of PTC are not evident (C). Cribriform-morular variant of PTC showing pseudostratified tall columnar cells with abundant eosinophilic cytoplasm and elongated dark nuclei. The solid area shows a small whorl (morule) of squamoid tumor cells with peculiar nuclear clearing (D).

Received: December 15, 2019 Accepted: December 17, 2019

Corresponding Author: Chan Kwon Jung, MD, PhD

Department of Hospital Pathology, Seoul St. Mary's Hospital, College of Medicine, The Catholic University of Korea, 222 Banpo-daero, Seocho-gu, Seoul 06591, Korea Tel: +82-2-2258-1622, Fax: +82-2-2258-1627, E-mail: ckjung@catholic.ac.kr

\section{ORCID}

Chan Kwon Jung: https://orcid.org/0000-0001-6843-3708

\section{Conflicts of Interest}

C.K.J. is the editor-in-chief of Journal of Pathology and Translational Medicine. 